\title{
7. The Haus Man Cleansing at Nahu Rawa
}

\author{
Patrick F. Gesch and Jonathan Julius
}

On 22 April 2014 the front page headlines of The National read, 'Mass arrests - A group of 120 men and 69 juveniles have appeared in court over the alleged killings of eight people at a village in Madang last Monday' (Mark 2014b). One of the juveniles was 10 years old. The story went on to say that the provincial police commander, Sylvester Kalaut, had gone with a team of police officers to Sakiko settlement in the Ramu River valley, and from there, after a marathon court hearing by a Madang magistrate, had taken those arraigned to Madang's prison. The magistrate reported that the group had voluntarily surrendered after a raid on Sakiko settlement, for which they had prepared themselves by rubbing the brains and heart meat of previous victims over their own bodies.

Police commander Kalaut said that seven men had been killed and then a threeyear-old boy had been snatched from his mother's arms and also killed. One of the victims was from Jiwaka in the highlands and a strong retaliation for him was expected. One fear was said to be that these killings were related to cult practices, such as those that occurred with the Black Jesus of Amele up to 2013 (Matbob 2010; see also Marks 2013), or with the sanguma-finding cult of Tangu in western Madang (Gumar 2012). The evidence of this ritual, given in the newspaper report was that, 'People were slashed from the legs up and had their heads cut off'. The group doing the killings was identifying itself as haus man (the men's house as an initiation enclosure). They had killed these eight victims because they labelled them sorcerers for the newspaper, but in the local area the victims were termed by the Tok Pisin name, sanguma. The villages from which these men and youths came were given as Niniko, Gomumu and Ranara.

\section{The beginnings of haus man}

Gesch interviewed a local resident about these events. He is a teacher from Sepik, ${ }^{1}$ not long graduated but about 30 years of age, a fellow with an impressive physical appearance that helps to give him status in the community. He came to Niniko Primary School at the beginning of 2011 and won the confidence of the

\footnotetext{
1 The Sepik teacher referred to in the text is Jonathan Julius, who initiated the report on the Nahu Rawa killings after personally witnessing many things. Gesch has since then worked with Julius to draw up this report and to incorporate the developments as Julius is made aware of them. The writing was a collaborative work.
} 
local people. In August 2012 some men from the local villages came to him and asked him to write formal complaints about members of their families having been killed by sanguma from 1990 to 2010. They said they would use these reports as their complaints to the police. Following their instructions he also listed the names of the dead, numbering up to 100. The teacher was sufficiently sympathetic with the evils of sanguma to want to help this group, who were the beginnings of the haus man faction in the troubles that followed.

One weekday in 2013, the teacher took a run down to Gusap township, which is about 15 kilometres distant in the Ramu River valley, and then returned slowly to the mountain school. As he arrived at Tapimi village, he had the strange experience of hearing a pig cry out in the valley basin below, as if it was being killed, but crying in such a way that the cry came from every side. Passing through Tapimi hamlet he saw men and women were already running about bringing their belongings to the bush and garden houses. On arriving at Gomumu village he was told some men had fought each other and those from Tapimi had fled to Gomumu. In the daytime, Asumu Gausa, a woman of Gomumu, had been killed by sanguma. It was suspected that her spirit was put inside a pig and killed, which was the cause of the strange pig cry. On the weekend the situation had deteriorated and 17 houses had been burned and domestic animals killed at Tapimi, the place of Ronuwe, who was the chief suspect for the killing of Asumu. Duma Gausa, her younger brother, led the raid on the suspects' houses.

The following Sunday morning, in front of the Lutheran church, an assault was made on Ronuwe, as a group of men tried to kill him. Witnesses said that bush knives and tomahawks were swung directly and forcefully at his skull, but he was able to smile and remain standing. One report says they even tried to shoot him with cartridges, but the plastic cartridges bubbled up before they could be used. Nevertheless, Ronuwe was badly injured and they threw him back into his own village. The Gomumu village councillor, Dowena Gausa, older brother of Asumu, took him to a house and cared for him. The informant states that he inspected the body and could see no wounds remaining from the attack except under the soles of his feet. They took him down to Gusap health centre, and haus man members followed him with the intent of killing him. He was transferred to Lae but another attempt on his life was made so he was transferred to Goroka, where he recovered.

\section{Haus man deals out justice to the sanguma}

In October 2012, a well-known sanguma man from Numbaia village, Peter Binaru, came to the village Gomumu, in a manner which local people took to be 
ominous. It was he who had sat with Asumu when she was sick, and in a casual manner had touched her, by which it was said that he had taken her spirit, so that she could be killed elsewhere by sanguma.

Peter Binaru came to pursue the dispute started in Gomumu. He went under a high post house with his group of supporters, and waited for the haus man people to gather so they could resolve the matter. As the haus man men approached the house, one of Binaru's men shot an arrow into the haus man group wounding a man, Tau, on his shoulder. Enraged, the haus man group set the house on fire. Binaru and his supporters went upstairs, waiting desperately for a chance to escape the fire and the haus man attackers. In the heat of the battle, Binaru was killed, sliced up and dumped before a toilet. Binaru's grade 6 son, Sauke, was also killed and cast out into a field. Everyone was forbidden to cry for Binaru and his son. That evening a very dark cloud came into the valley and lightning lit up the whole darkened area as a threatening sign.

After this, killing continued on both sides and the teachers from elsewhere were sent to Madang for their own safety. Bodies were lying unburied in the bush around the villages. Peter Binaru's sons kidnapped a 12-year-old boy and a woman who were related to Duma and sent them across the Ramu valley to Kafe near Kainantu. The kidnappers' motives were to put demands on the haus man. By the beginning of 2014, only the woman had been released and sent back to Gomumu.

The teachers tried to return to duties in 2013. They did not believe the description of the events that said there was a cult going on. They could see nothing like ritual activities. It was more like tribal fighting, and haus man was simply the small building for initiations ${ }^{2}$ where Duma's supporters gathered. At the end of the second term of the school year, the teachers had lined up the students for parade one morning early, when suddenly they all ran away into the bush. There had been a report of finding a body on the road, covered in many cuts. A teacher photographed the body, which was turned over for him to witness the many cuts. Duma and his men came to the teacher's house to see the photographs that evening and to blow on him and bespell him so that he could sleep peacefully after what he had witnessed. The teacher's family were not at ease, and could smell a strong smell of blood everywhere.

The sliced-up man was Yakasi, a brother of Ronuwe, the sanguma man who was said to have killed Asumu by sanguma practice. Presumably Yakasi was also a sanguma. Duma, at this visit to the Sepik teacher, indicated clearly that he himself was the one who had killed Yakasi. The ruling dictum is that to kill a sanguma you have to be a sanguma, or know sanguma ways.

2 This initiation is highlighted by the penile dorsal slit ritual common to much of Madang. 
Some time after this my informant was invited to go on a pig hunt. Perhaps 'pig hunt' was a euphemism, because they told him to bring his camera, and they went about in the gardens destroying food when they found no one to kill.

There is a scaled-up fear of sanguma practices among the general population of Madang. Warfare and killing in anger have their reasons, but sanguma ritual seems beyond reason. In opposition to the claim about the use of ritual, my informant does not acknowledge any ritual practice as claimed in the newspaper article of April 2014. He remembers the occasion of Dorothy Mark's first article (Mark 2014a), when 106 men went to find a couple of suspected sanguma. They were saying, 'My bush knife must see blood'. So after one man was killed, everyone cut him further to put blood on their knives. The first man photographed apparently died in the course of a knife attack, not at the end of proceedings. Others were diced into small pieces and their flesh dispersed to the winds. This was warfare, not religious ritual and the methods of dealing with this are evil but more straightforward.

\section{Government mediation begins}

In April 2013 the government sent six police officers into Tauta station to investigate the haus man movement. The first mediation between the groups took place under the leadership of a Lutheran pastor at Ranara station. Police said they would return with their report, but they have not done so, and this has remained one of the enduring complaints of the local villagers, that there was no follow-up on government action. In preparation for the coming of the police mediators, the Sepik teacher and his teacher colleagues had been asked to make some banners with the local youth, so they prepared signs that read, 'Nahu Rawa youth say "no" to sanguma practices'. By November 2013 the community was saying to the teachers, "The government has neglected us entirely. You teachers are the last service we have from outside. You cannot leave now.'

Once again at the beginning of 2014 the teachers tried to restart the school. For three weeks no student put in an appearance. At the beginning of the fourth week, there was an assembly, but that very day a girl was found killed at Duma's house. After that the children did not come again. They knew that haus man would 'move' now. They were meeting at a place called Yuriengo. Generally there were the three sides to the dispute: the haus man, the sanguma and about four or five men who tried to remain neutral. When the haus man moved, they went to Pisiko and killed four people. This story was covered by The National in late February 2014 (Mark 2014a). Duma managed to kill a few more, and the sanguma retaliated by killing a member of the haus man. The sanguma group brought the body of a boy to Serengo village, but haus man intervened the 
funeral and killed three more, putting their bodies in the toilets. Killings on every side followed, and even some neutral men were killed now. By the time the first article (Mark 2014a) went to press 60 men were said to have died in this spate of killings.

\section{Finding and killing sanguma}

Who are these sanguma who are labelled as killers, and yet seem to suffer the brunt of revenge killing by the community?

According to the local understanding, the way to tell a sanguma is as follows: Someone accused is asked to produce their vital arsenal of kawar (ginger) or tree barks. If they do so, and show true repentance for their evil deeds of witchcraft, they are approved to return to the community. Anyone compromising in this surrender or trying to run away is obviously guilty, to be pursued and killed. There are said to be about 300 sanguma men in the larger area. Gomumu can declare there are 10 sanguma in their village, and each one must have two or three sons who follow his ways.

On reviewing the course of events, my informant feels that it started with the sanguma killing the woman, Asumu, then haus man paying back the killing on the sanguma person, Binaru, in Gomumu. Other village people said, 'That's good, come and do the same for us'. When asked to reflect on the group identity of the people called sanguma, the teacher denied any systematic connection with language differences or village location. The sanguma people from the mountain stayed together at Sakiko settlement in the Ramu River plains, which has now been burned to the ground. They are probably best referred to as 'sanguma suspects'. They represent people from as many as 15 villages. According to my informant, perhaps the best identification of the sanguma people is that they are recent migrants to their villages. They were adopted into the village some generations ago, but now find themselves very much short of land, so they have resolved to remove the original landowners by sanguma magic. The sanguma can at times be referred to as bastard pikinini (illegitimate children of the village) as they try to gain ground and emerge as leaders in the community. They confuse the story of landownership in the local areas.

What the people want most of all is for the government to be consistent in their mediation efforts. There is a protest against religious forms of killing. There is the sanguma side of the argument largely unheard by the outside world. Obviously a large campaign of reconciliation and retributive justice, as for Bougainville, is necessary at this time. ${ }^{3}$

3 For this, see the experiences and prescriptions given in Howley (2002). 
Talking it Through

\section{References}

Gumar, P. 2012. Eradicating Sorcery Backfires on Villagers. The National, 13 July, p. 65.

Howley, P. 2002. Breaking Spears and Mending Hearts: Peacemakers and Restorative Justice in Bougainville. Annandale NSW: The Federation Press.

Mark, D. 2014a. Community Living in Fear. The National, 27 March.

Mark, D. 2014b. Mass Arrests. The National, 22 April, p. 1.

Marks, K. 2013. Hacked, Slashed and Castrated: How 'Cannibal' Cult Leader 'Black Jesus' Steven Tari Met His Death. The Independent, 2 September. www. independent.co.uk/news/world/australasia/hacked-slashed-and-castratedhow-cannibal-cult-leader-black-jesus-steven-tari-met-his-death-8795240. html, viewed 13/5/2014.

Matbob, P. 2010. Black Jesus Behind Bars; but Says He Did Nothing Wrong. Islands Business, December, p. 29. 
This text is taken from Talking it Through: Responses to Sorcery and Witchcraft Beliefs and Practices in Melanesia, edited by Miranda Forsyth and Richard Eves, published 2015 by ANU Press, The Australian National University, Canberra, Australia. 